\title{
The Profile of Self-Efficacy Beliefs among English Teachers without L2 Teaching Degree
}

\author{
Wiwiet Eva Savitri \\ Universitas Negeri Surabaya \\ Surabaya, Indonesia \\ wiwieteva@unesa.ac.id
}

\author{
Syafi'ul Anam \\ Universitas Negeri Surabaya \\ Surabaya, Indonesia \\ syafiul.anam@unesa.ac.id
}

\author{
Suvi Akhiriyah \\ Universitas Negeri Surabaya \\ Surabaya, Indonesia \\ Suviakhiriyah@unesa.ac.id
}

\begin{abstract}
Teachers' belief of their own competence, especially subject-matter and pedagogical, is instrumental in teaching success and failure. This selfbelief, commonly called self-efficacy, is believed to determine teachers' effort, persistence, goal setting, and aspirations for themselves and their students. Despite playing the crucial motivational role, self-efficacy of EFL teachers has yet to receive due attention, let alone on that of teachers who have no English teaching degree. In addition, research on this self-belief mainly focuses on its link with other constructs, and few have looked into its source of information. Therefore, this study examined 1) the level of self-efficacy beliefs in English and pedagogical competence among English teachers in an Indonesian university, and 2) how the sources of information, as postulated by Bandura, related to the teachers' English and pedagogical selfefficacy. The data were collected from Academic English teachers who did not have English teaching degree through a questionnaire. Results indicated that teachers had quite firm confidence in English skill and classroom management, but not in instructional strategies. Additionally, social persuasion had the strongest link with self-efficacy in English, instructional strategies, and classroom management. These findings could shed light on the nature of such teachers' selfbelief and how the belief is shaped.
\end{abstract}

Key words: self-efficacy, EFL teachers, pedagogical competence, source of self-efficacy

\section{INTRODUCTION}

As the world gets more globalized, people all over the world are expected to get no trouble in communicating with each other, using any languages. Yet, the ability to use international languages like for example English is getting crucial. In Indonesia, the most common international language mastered is English. It is taught formally at schools and it is set in school curriculum and tested as one of national school exam subjects. Teachers of English are mostly those who have English teaching qualification and professional recognition. However, there are also institutions which do not require their English teachers to have English teaching background or degrees. In recruiting English teachers, such institution consider that it is sufficient for English teachers to show expected English mastery. Another reason found in a university in Surabaya where lecturers without English teaching qualification are assigned to teach English because of insufficient number of available English lecturers in that university to serve all faculties and departments. Those lecturers are assigned to teach English subject in which they have to prepare students to face the university English test. Without being able to pass the passing grade of this test, the students will not be considered appropriate to graduate from the university. Hence, the English lecturers carry heavy burden on their shoulders to make the students ready to face the test.

For lecturers with English teaching qualification, this task seems easier to handle due to the trainings they had for their degrees. They have certificate that prove they have good English mastery and know how to pass on their knowledge of English to their students for they have undergone trainings on English teaching method. Yet, it is questioned whether lecturers without English teaching qualification are able to cope with the task well. Their English proficiency is still doubted to be adequate to act as English instructors. 
Even if they have excellent English, there are still questions on what methods they use to teach English.

Preliminary observation indicated that those lecturers without English teaching degree do not seem confident in teaching English. Although the teaching materials are provided with answer keys and power point presentation files, some parts of the provided teaching materials are still often confusing for them. They mostly rely on the answer keys. Moreover, they might get confused to find comfortable ways to explain the materials properly. These condition may affect the quality of their teaching. Lecturers who are not confident will be busy with the thought on how to make themselves feel more comfortable rather than on how to organize the class and pass on the materials properly. It will not occur if they have high selfefficacy. According to Pajares [19], self-perceptions of capability help determine what individuals do with the knowledge and skills they have. Thus, although having no English teaching degree, high self-efficacy might help them to feel confident and comfortable in teaching English, and turn them to be effective English lecturers. They will not easily give up whenever they find difficulties in finishing their tasks, either. People who doubt their capabilities shy away from difficult tasks, give up quickly, and have low aspirations [4]. On the contrary, people with high degree of self-efficacy tend to work hard and persist in doing their tasks because their self-efficacy will cause them to improve their strategies, rather than look for excuses, whenever they face setbacks [10] . Previous studies have given much attention how teacher self-efficacy links with other constructs or teaching performance[15], [25]-[27] .

Despite a growing body of research on EFL teacher self-efficacy, few have sought to identify the source of self-efficacy information[16][20], let alone among teachers who did not have English teaching degree in the Indonesian context. Therefore, this study attempts to to reveal the self-efficacy in English and pedagogical skills among the English teachers without English teaching qualification, and to find out how the sources of information for self-efficacy relate to the teachers' self-efficacy.

\section{LITERATURE REVIEW}

\section{A. Nature of Self-Efficacy}

Self-efficacy is defined as one's belief in their capabilities or one's perception of their ability to perform a particular task [5], [14]. Different from selfconfidence and self-esteem, self-efficacy is more specific and circumscribed [10]. Self-efficacy is a differentiated set of beliefs linked to distinct realms of functioning, concerned with self-regulation of thought processes, motivation, and affective and physiological states [4]. Because self-efficacy pertains to specific tasks, people may simultaneously have high self- efficacy for some tasks and low self-efficacy for others. How effectively they will perform a given task can be predicted more easily from their self-efficacy [10].

\section{B. Role of Self-Efficacy for English Teachers}

In educational research, self-efficacy has received increasing attention, especially in studies of academic motivation and of self-regulation [21]. Self-efficacy beliefs of teachers are related to their instructional practices, various student achievement, and teacher well being [15], [27]. Teachers with high self-efficacy are also believed to have optimistic view of students' motivation, be able to adjust classroom based on the need, and get students to study by triggering intrinsic encouragement and positive reward [25], [26].

Teacher efficacy has become an important construct in teacher education, and teacher educators should continue to explore how teacher efficacy develops, what factors contribute to strong and positive teaching efficacy in varied domains, and how teacher education programs can help pre-service teachers develop high teacher efficacy. According to Guskey, high teacher efficacy can promote or inhibit conceptual change [8], [9]. Teachers with high confidence in their instruction may be highly resistant to change the way they teach because of the confidence they have in themselves. However, teachers who are highly confident in their instruction may also be confident enough to try any conceptual changes.

\section{Source of self-efficacy}

Individuals grow their self-efficacy through processing information obtained from four major sources of information: mastery experiences, vicarious experiences, verbal persuasion, and physical and emotional states [4]. Mastery experience, resulting from past successful and unsuccessful completion of tasks, may have an enduring effect on how confident they are to perform subsequent tasks [18]. Empirical evidence [11], [23] lends support to Bandura's theory that mastery experience is the key source of self-efficacy. Vicarious experiences, or observing other people's task completion, is another source of self-efficacy [4]. Seeing others complete difficult tasks successfully can boost individuals' confidence that they are able to so as well; conversely, seeing others fail despite persistent effort may undermine their conviction of their own ability.

Social persuasion is another source of information which can boost learners' beliefs in their capabilities. Verbal persuasion will effectively raise learners' confidence if they are expected to achieve realistic objectives [2]. Young students who are unable to make an accurate judgement of their performance need others' evaluative feedback and appraisal [23]. For this reason, teachers and parents 
should provide evaluative feedback which helps the students understand better their actual performance, rather than merely praise them [11]. Parents, teachers, and significant others also need to be aware that verbal and nonverbal messages they provide to young learners can be either empowering or undermining the learners' confidence in their capabilities.

Physiological and emotional states, such as anxiety, stress, fear, nervousness, sweating, can also provide information about learners' capabilities [4]. Novice teachers may be aware of their self-efficacy through interpreting their bodily and emotional signals when faced with challenging academic tasks. For example, teachers with low efficacy may view their trembling as an indicant of vulnerability to poor performance or, instead, as determination to succeed [3]; or teachers who feel less anxious when teaching may indicate that they are competent, which then can increase their self-efficacy.

The information from the four sources is interpreted by teachers. The interpretation depends on such factors as prior attainment, perception of competence, task difficulty, expended effort and time, and types and intensity of emotional symptoms [22]. L2 research in self-efficacy [20] supports Bandura's hypotheses of sources of self-efficacy and reveals other sources. A qualitative study by Phan and Locke showed that teachers beliefs in their capabilities were also affected by cultural and contextual factors[20]. Other L2 studies [6], [7], [16] also emphasized the influence of contextual, teacher and student factors on the up and down of teacher self-efficacy.

\section{RESEARCH QUESTIONS}

There are two research questions underlying this study. They are:

1. What is the level of self-efficacy beliefs in English and pedagogical competence among English teachers in an Indonesian university?

2. How do the sources of information, as postulated by Bandura, relate to the teachers' English and pedagogical self-efficacy?

\section{METHODS}

There were 23 English teachers from a public university who participated in this study. They were lecturers with non English education background who were assigned to teach English for students of non English departments. Data were collected through two questionnaires, namely Teacher Self-efficacy Questionnaire and Sources of Teacher Self-efficacy Scale. The former was adapted from The Ohio State teacher efficacy scale [13] English Teacher selfefficacy [6]. The questionnaire consisted of three subscales: English self-efficacy, self efficacy in classroom management, self-efficacy in instructional strategies. The latter was adapted from a scale developed by Usher and Pajares', and it involved items about four sources of information postulated by Bandura. [23][4]

\section{RESULTS AND DISCUSSION}

1) Level of self-efficacy for English and pedagogical competence

Results show that all the medians of the three subscales in the teacher self-efficacy questionnaire were all above the middle point in the 6-point Likert scale used. As Table 1 indicates, the English teachers had confidence in their English and managing their classroom $(M d=5)$. The teachers were also fairly confident in their ability to apply varied instructional strategies $(M d=4)$. Likewise, the median of the twelve items ranged from 4 to 5 . The teachers perceived themselves capable of understanding English texts, speaking as well as writing in English for instructional purposes, controlling disruptive students, keeping instructional activities running well, getting students obey classroom rules, managing group work, and asking questions $(M d=5)$. However, their belief in their ability to respond students' questions, develop materials, implement varied instructional strategies, and write scientific papers was lower $(M d=4)$. The findings are interesting in that despite not having an English teaching background the teachers had a moderate level of self-efficacy in their English and pedagogical skills.

TABLE I. THE MEDIAN OF THE TWELVE ITEMS OF THE TEACHERS' SELF-EFFICACY

\begin{tabular}{|c|c|c|}
\hline Subscales & Self-efficacy for... & Median \\
\hline \multirow[t]{4}{*}{$\begin{array}{l}\text { English self- } \\
\text { efficacy }\end{array}$} & $\begin{array}{l}\text { using English as the instructional } \\
\text { language }\end{array}$ & 5 \\
\hline & understanding English texts & 5 \\
\hline & $\begin{array}{l}\text { writing in English for instructional } \\
\text { purposes }\end{array}$ & 5 \\
\hline & writing scientific papers & 4 \\
\hline \multirow{4}{*}{$\begin{array}{l}\text { Self- } \\
\text { efficacy in } \\
\text { classroom } \\
\text { management }\end{array}$} & Controlling disruptive students & 5 \\
\hline & $\begin{array}{l}\text { establishing routines to keep } \\
\text { activities running smoothly }\end{array}$ & 5 \\
\hline & $\begin{array}{ll}\text { establishing } & \text { classroom } \\
\text { management for groups } & \\
\end{array}$ & 5 \\
\hline & $\begin{array}{l}\text { getting students follow classroom } \\
\text { rules }\end{array}$ & 5 \\
\hline \multirow{4}{*}{$\begin{array}{l}\text { Self- } \\
\text { efficacy in } \\
\text { instructional } \\
\text { strategies }\end{array}$} & crafting good questions & 5 \\
\hline & responding to questions & 4 \\
\hline & $\begin{array}{l}\text { crafting and adjusting lessons to } \\
\text { the proper levels of the students }\end{array}$ & 4 \\
\hline & $\begin{array}{ll}\text { implementing } & \text { alternative } \\
\text { instructional strategies } & \end{array}$ & 4 \\
\hline
\end{tabular}


The finding does not support Lee's study, revealing that EFL teachers who regarded British and American English as the best model exhibited a low sense of self-efficacy classroom management and oral English communication[17]. The difference might be because of some possible factors, like cultural context and teachers' perception of English as an international language. The moderate self-efficacy belief in English and classroom management among the teachers in the current study is a positive sign because a very high level of self-efficacy could instead be an obstacle in improving teaching practices [24]. Extremely confident teachers might think that there is no immediate need to develop their professional and pedagogical skills. However, with moderate selfefficacy English teachers are likely to work harder, be more resilient in the face of difficult problems, use cognitive resources, and exercise control to perform given tasks [4]. That the teachers displayed the fairly moderate self-efficacy in instructional strategies might make sense. The teachers did not have an English teaching degree and accordingly they might have inadequate pedagogical knowledge, especially about how to teach and assess their students.

2) The relationship between sources of information and teachers' self-efficacy

A number of Spearman analyses were conducted to examine whether the four sources of information have significant correlation with the teachers' selfefficacy. As Table 2 indicates, mastery experience only had a strong, positive link with self-efficacy in English $(r=.508, p<.05)$, with more successful completion of past tasks associated with a higher level of self-efficacy in English. Interestingly, vicarious experience was only significantly related to selfefficacy for instructional strategies $(r=-.419, p<.05)$. This suggests that observing others perform tasks well can lead to the decrease in teachers' self-efficacy in instructional strategies. Unlike mastery and vicarious experiences, social persuasion had a strong positive correlation with self-efficacy beliefs in English $(r=$ $.501, p<.05)$, in classroom management $(r=.626$, $p<.05)$, and in instructional strategies $(r=.517, p<$. $05)$. Teachers who received more positive feedback and encouragement are likely to have a higher sense of confidence in their English and pedagogical abilities. Quite similarly, emotional and physiological states had a significant negative correlation with selfefficacy in English $(r=-484, p<.05)$, in classroom management $(r=-.468, p<.05)$, and in instructional strategies $(r=-.527, p<.05)$. The findings imply that teachers with firm self-efficacy are less likely to feel anxious and nervous while teaching in the class.
TABLE II. SPEARMAN RHO CORRELATIONS BETWEEN SOURCES OF INFORMATION AND TEACHERS' SELF-EFFICACY

\begin{tabular}{|c|c|c|c|}
\hline & $\begin{array}{l}\text { English } \\
\text { self- } \\
\text { efficacy }\end{array}$ & $\begin{array}{l}\text { Self-efficacy in } \\
\text { classroom } \\
\text { management }\end{array}$ & $\begin{array}{c}\text { Self-efficacy } \\
\text { in } \\
\text { instructiona } \\
\text { I strategies }\end{array}$ \\
\hline $\begin{array}{c}\text { Mastery } \\
\text { experience }\end{array}$ & $.508 *$ & .332 & .384 \\
\hline $\begin{array}{c}\text { Vicarious } \\
\text { experience }\end{array}$ & -.395 & -.050 & $-.419^{*}$ \\
\hline $\begin{array}{c}\text { Social } \\
\text { persuasion }\end{array}$ & $.501^{*}$ & $.626^{*}$ & $.517^{*}$ \\
\hline $\begin{array}{l}\text { Emotional } \\
\text { and } \\
\text { physiologic } \\
\text { al states } \\
\end{array}$ & $-.484 *$ & $-.468^{*}$ & $-.527^{*}$ \\
\hline
\end{tabular}

The significant correlations between the four sources of information and one or two of the selfefficacy beliefs supports the postulate proposed by Bandura that past experience, observing others' performance, social persuasion, and emotional and physiological states as the factors of self-efficacy[4]. Like previous studies[16], [20], social persuasion, rather than mastery experience, was the strongest factor of teacher self-efficacy. This finding contradicts what has been widely believed that mastery experience is the most potent factor of self-efficacy. Interestingly, the current study also showed that emotional and physiological states had stronger relations with self-efficacy than mastery and vicarious experiences did. This certainly does not accord with the study by Tschannen-Moran \& McMaster [12]. The inconsistent findings are likely due to the different cultural and contextual differences, as indicated by Moradkhani and Haghi, as well as Phan and Locke [16], [20].

\section{CONCLUSION}

The study revealed that English teachers who did not have L2 teaching qualification had confidence in their English and managing their classroom, as well as in their ability to apply varied instructional strategies. However, their belief in their ability to respond students' questions, develop teaching materials, implement varied instructional strategies, and write scientific papers was lower. This finding might make sense since their degree was not related to teaching English that they might have inadequate pedagogical knowledge of English language teaching. The study also indicated that emotional and physiological states had stronger relations with self-efficacy than mastery and vicarious experiences did. Thus, teachers who received more positive feedback and encouragement are likely to have a higher sense of confidence in their English and pedagogical abilities. This finding supports the postulate proposed by Bandura and the findings of previous studies that cultural and contextual differences influence factors of selfefficacy. 


\section{REFERENCES}

[1] P. T. Ashton and R. B. Webb, Making A Difference: Teachers' Sense of Efficacy and Student Achievement. New York: Longman, 1986.

[2] A. Bandura, Social foundations of thought and action: A socio cognitive theory. New Jersey: Prentice-Hall, Inc., 1986.

[3] A. Bandura, Self-efficacy in changing societies. New York: Cambridge University Press, 1995.

[4] A. Bandura, Self-efficacy: The exercise of control. New York: Freeman \& Co., 1997.

[5] A. Bandura, "On the Functional Properties of Perceived Self-Efficacy Revisited," J. Manage., vol. 38, no. 1, pp. 944, Jan. 2012

[6] Basikin, "Self-efficacy belief of secondary English teachers in Yogyakarta province of Indonesia," Monash University; Clayton UA, 2008.

[7] Z. Chen and A. S. Yeung, "Self-efficacy in Teaching Chinese as a Foreign Language in Australian Schools," Aust. J. Teach. Educ., vol. 40, no. 8, 2015.

[8] T. R. Guskey, "Context variables that affect measures of teacher efficacy," J. Educ. Res., vol. 81, no. 1, pp. 41-47, 1987.

[9] T. R. Guskey, "Teacher self-efficacy, self-concept, and attitudes toward the implementation of instructional innovation," Teach. Teach. Educ., vol. 4, no. 1, pp. 63-69, 1988.

[10] P. A. Heslin and U. C. Klehe, “'Self-efficacy' in S. G. Rogelberg (Ed.)," in Encyclopedia of Industrial/Organizational Psychology, 2nd ed., Thousand Oaks: Sage, 2006, pp. 705-708.

[11] G. Joët, E. L. Usher, and P. Bressoux, "Sources of selfefficacy: An investigation of elementary school students in France.," J. Educ. Psychol., vol. 103, no. 3, pp. 649-663, 2011.

[12] M. Tschannen-Moran and P. McMaster, "Sources of Self-Efficacy: Four Professional Development Formats and Their Relationship to Self-Efficacy and Implementation of a New Teaching Strategy,” Elem. Sch. J., vol. 110, no. 2, pp. 228-245, Dec. 2009.

[13] M. Tschannen-Moran and A. W. Hoy, "Teacher efficacy: capturing an elusive construct," Teach. Teach. Educ., vol. 17, pp. 783-805, 2001.

[14] D. McCoach, R. Gable, and J. Madura, Instrument Development in the Affective Domain. New York: Springer, 2013.

[15] A. Mojavezi and T. M. P., "The impact of teacher selfefficacy on the students' motivation and achievement," Theory Pract. Lang. Stud., vol. 2, no. 3, 2012.

[16] S. Moradkhani and H. Sara, "Context-based sources of EFL teachers' self-efficacy: Iranian public schools versus private institutes," Teach. Teach. Educ., vol. 67, pp. 259-269, 2017.

[17] J.-A. Lee, "Teachers' sense of efficacy in teaching English, perceived English proficiency, and attitudes towards the English language: A case of Korean public elementary teachers," The Ohio State University, The United, 2009.

[18] F. Pajares, "Motivational role of self efficacy beliefs in selfregulated learning. In D. H. Schunk \& B. J. Zimmerman (Eds.)," in Motivation and self-regulated learning: Theory, research, and application, New York: Lawrence Erl, 2008, pp. 111-140.

[19] F. Pajares, "Current Directions in Self-efficacy Research," 2017.

[20] N. T. T. Phan and T. Locke, "Sources of self-efficacy of Vietnamese EFL teachers: A qualitative study," Teach. Teach. Educ., vol. 52, pp. 73-82, 2015.
[21] P. R. Pintrich and D. H. Schunk, Motivation in education: Theory, research, and applications. Englewood Cliffs, NJ: Prentice Hall, 1995.

[22] D. H. Schunk, "Self-efficacy and education and instruction. In J. E. Maddux (Ed.)," in Self-efficacy, adaptation, and adjustment: Theory, research, and applications, New York: Plenum, 1995, pp. 281-303.

[23] E. L. Usher and F. Pajares, "Sources of academic and selfregulatory efficacy beliefs of entering middle school students," Contemp. Educ. Psychol., vol. 31, no. 2, pp. 125141, Apr. 2006.

[24] K. F. Wheatley, "The potential benefits of teacher efficacy doubts for educational reform," Teach. Teach. Educ., vol. 18, pp. 5-22, 2002.

[25] A. E. Woolfolk and W. K. Hoy, "Prospective teachers' sense of efficacy and beliefs about control.," J. Educ. Psychol., vol. 82, pp. 81-91, 1990.

[26] A. E. Woolfolk, B. Rosoff, and W. K. Hoy, "Teachers' sense of efficacy and their beliefs about managing students," Teach. Teach. Educ., vol. 6, pp. 137-148, 1990.

[27] M. Zee and H. M. Y. Koomen, "Teacher self-efficacy and its effects on classroom processes, student academic adjustment, and teacher well being: a synthesis of 40 years of research," Rev. Educ. Res., vol. 86, no. 4, 2016. 